\title{
ИНСТИТУЦИОНАЛЬНЫЕ АСПЕКТЫ НАЛОГООБЛОЖЕНИЯ: ЭКОНОМИЧЕСКАЯ БЕЗОПАСНОСТЬ И ДЕЯТЕЛЬНОСТЬ ХОЗЯЙСТВУЮЩЕГО СУБЪЕКТА
}

\author{
(c) 2021 Чернов Сергей Борисович \\ кандидат экономических наук, доцент, \\ доцент кафедры мировой экономики и международных экономических отношений \\ Государственный университет управления, Россия, Москва \\ Email: chernov_s_b@mail.ru \\ (c) 2021 Захарова Александра Вячеславовна \\ кандидат экономических наук, доцент, \\ доцент кафедры бухгалтерского учета, аудита и налогообложения \\ Государственный университет управления, Россия, Москва \\ Email: avzakharova@mail.ru
}

В статье авторами рассматриваются институциональные аспекты налогообложения и выделяются возникающие при этом проблемы экономической безопасности, влияющие на деятельность хозяйствующего субъекта. Обосновано предлагается использовать возможности совершенствования правовых норм и юридических отношений для повышения экономической безопасности хозяйствующего субъекта. По мнению авторов, использование методов налогового регулирования экономики является приоритетным направлением экономического развития общества.

Ключевые слова: налоги, налогообложение, государственное регулирование, автоматические стабилизаторы, теневая экономика, экономическая безопасность.

Категория «налоги» выступает одним из первых в истории финансовых институтов. Их возникновение связано с разделением общества на социальные группы и появлением государства. Считается, что необходимость налогов предопределяется непосредственно функциями государства. Государству необходимы доходы, которые оно получает из различных источников. Это налоговые и неналоговые доходы. Поэтому экономическое содержание налогов заключается во взаимоотношениях государства и хозяйствующих субъектов по поводу формирования государственных доходов. В результате изъятия налоги становятся собственностью государства и используются для выполнения возложенных на него конституционных полномочий. Налоговые отношения представляют собой часть финансовых отношений, поскольку важным их признаком является денежный характер (реальная сумма денежных средств мобилизуется в бюджет), однако это не обязательное условие существования налога (истории известно множество примеров натурального обложения). Процесс «отчуждения» стоимости происходит на условиях безвозвратности.

Определение налога дается в ст.8 Налогового кодекса России [1]. В существующем определении налога, на наш взгляд, имеются определенные правовые неточности: обязательность, не тождественна законности установления; взимание налога, а не его уплата противоречит самостоятельности налогоплательщика и нивелирует налоговый контроль, отчуждение аналогично конфискации может произойти законно только по решению суда; взыскание налога (ст.45 п.2 пп.2) за счет иного (кроме денежных средств) имущества не связано с платежом. Определение не учитывает, что современное развитие экономики предусматривает уплату налога не только юридическими и физическими лицами, но и домохозяйствами (семейное налогообложение), консолидированными налогоплательщиками. Если в понятии не зафиксирована регулярность уплаты, то к налогу можно ошибочно отнести штрафы. Это приводит к необходимости уточнений, дополнений в других статьях Налогового кодекса, разъяснений контролирующих органов и решений судебных инстанций в результате разрешения налоговых споров. Усложнение налогового законодательства увеличивает издержки хозяйствующих субъектов на услуги юридических фирм, а также возрастает доля за- 
работной платы юристов фонде оплаты труда организации. Тем самым может ухудшиться финансовое положение хозяйствующих субъектов.

В налогах концентрируется вся совокупность интересов любой национальной экономики, поэтому налог является комплексной категорией, т.е. одновременно экономической (так же как прибыль, цена, доход), финансовой (имеет денежную форму) и правовой (уплачивается по закону). Многочисленные последствия влияния налогов на экономические и социальные процессы трактуются как их разнообразные функции: фискальная, экономическая, и контрольная. Количество функций, присущих налогам благодаря их участию в перераспределительном процессе является предметом дискуссий. Например, выделяют распределительную или перераспределительную функцию, которая более адекватна финансам, а не налогам. Отдельные ученые выделяют политическую функцию [2]. В то же время, функции налогов определяются задачами государственной налоговой политики и показывают, каким образом реализуется их назначение при построении налоговой системы государства. Система налогов Российской Федерации представляет собой их совокупность, объединенных в зависимости от компетенции уровня государственной власти и управления. По принадлежности к уровням власти и управления в связи с федеративным устройством Российской Федерации подразумевается разграничение и распределение налогов ещё между уровнями бюджетной системы страны [3]. Уровень власти и управления в налоговой системе России рассматривается как совокупность отношений в налоговой сфере между законодательными и исполнительными органами Российской Федерации и ее субъектов, органами местного самоуправления, которые обусловлены необходимостью реализации закрепленных в Конституции полномочий.

Основная цель такого распределения состоит в обеспечении единства государства и стабильности его социально-экономического развития на основе удовлетворения потребностей в денежных средствах всех уровней власти за счет перераспределения налогов между звеньями бюджетной системы. Например, такие федеральные налоги как налог на прибыль и налог на доходы физических лиц почти полностью поступают в бюджеты субъектов Российской Федерации. Аналогично - государственная пошлина и акцизы на отдельные группы товаров участвуют в формировании доходной базы региональных бюджетов. Тем не менее, остается нерешенным вопрос с дотационными регионами, что связано с общим уровнем их экономического развития. Хозяйствующие субъекты, расположенные в дотационных регионах, как правило, не могут рассчитывать на финансовую поддержку и находятся в худшем стартовом положении по сравнению с фирмами, зарегистрированными в благополучных субъектах Российской Федерации.

Усиление же фискальной направленности налогов для получения максимально возможных поступлений в бюджет приводит к различиям в правилах ведения предпринимательской деятельности, регулируемых гражданским кодексом, обычаями делового оборота и нормами налогового кодекса. В результате, у налогоплательщиков возникает необходимость рассчитывать доходы и расходы для целей налогообложения, отлично от аналогичных показателей при ведении учета операций хозяйственной деятельности. Трудности совмещения бухгалтерского и налогового учета связаны с различием применяемых правил [4]. Такое «виртуальное» формирование показателей для налоговой отчетности приводит к нерациональному использованию трудовых и материальных ресурсов хозяйствующими субъектами. Причина этому исключение потенциальных рисков, возникающих в результате возможных ошибок в расчете налоговых обязательств, либо невозможности обоснования понесенных производственных затрат. Риски как существенный фактор планирования налоговых платежей требуют от хозяйствующего субъекта дополнительных издержек, особенно если это связано с исчислением налога на прибыль в бухгалтерском и налоговом учете и НДС. В качестве примеров можно привести «противостояние» налогоплательщиков и государства, в лице налоговых органов, в вопросах, связанных с «необоснованной налоговой выгодой», которое пока не удаётся преодолеть, а также уведомительный порядок уплаты поимущественных налогов с юридических лиц. Негласно установленное правило контролирующих органов требовать от налогоплательщика доказательств своей «невиновности» во всех случаях, связанных с таким расчетом налога, когда его сумма уменьшается (расходы, вычеты, льготы) приводит к налоговым спорам, когда налогоплательщик должен доказывать свою правоту, а не 
контролирующие органы - его вину, если таковая имеется, как это принято в процессуальном производстве и закреплено в п.6 ст.108 НК РФ. Всё это, безусловно, не способствует безопасности ведения бизнеса и его развития, а, значит, приводит и к негативным социальным последствиям.

Общеизвестно и научно обоснованно, что косвенные налоги или налоги на потребление (НДС, акцизы) - наиболее привлекательные для государства доходные источники с точки зрения их уплаты и администрирования. При этом их доля в консолидированном бюджете составляет более 20\% [5]. Прямые же налоги (налог на прибыль, имущество, доход, рента), составляющие около 70\%, напрямую не влияют на потребление, но включаются в расходы организации, и могут на рынках несовершенной конкуренции перекладываться на потребителей готовой продукции. В результате налоговое бремя физических лиц становится выше, чем юридических. Это доказывает, что налоги выступают социальным институтом. А значит, устанавливая налоговые платежи, государству необходимо учитывать и эту функцию налога.

Получаемые налоги государство использует для финансирования создания общественных благ и предоставления их на безвозмездной основе всем членам общества, а также для субсидирования отдельных хозяйствующих субъектов. Таким образом, возникает проблема «безбилетника». Все организации и физические лица не возражают быть получателями общественных благ, но в тоже время тяжесть налогообложения стремятся переложить на других субъектов. Отсюда у части предпринимательского сообщества может сформироваться негативное отношение к легальным методам ведения бизнеса и возникнет мотивация к участию в теневой экономической деятельности. В результате общество сталкивается с сокрытием выручки, завышением в бухгалтерских документах затрат, незаконным использованием налоговых льгот и появлением фирм-однодневок.

Итак, налоги выступают как неотъемлемый атрибут государства, представляющего и защищающего интересы общества, гарантирующего выполнение установленных правил общественной жизни. Очевидно, что без фискального института нет государственности, а значит, нет условий для развития бизнеса. Безопасность последнего зависит не только от финансовых воз- можностей создания собственных служб, работающих в данной сфере, но и от степени развития правоохранительных органов, которые должны пресекать нечестные методы конкуренции тех хозяйствующих субъектов, которые решили связать свою деятельность с теневой экономикой. Таким образом, налоги являются необходимым условием существования как государства, так и бизнеса, несмотря на различные цели, задачи и интересы.

Социально-правовое направление институционализма, основанное Дж. Коммонсом (1862 г.-1945г.), приоритет экономического развития общества отдает юридическим отношениям и правовым нормам. Поэтому совершенствование налогового законодательства является важным фактором развития Российской Федерации. В последние годы налоговая реформа прежде всего была направлена на уменьшение налоговой нагрузки на бизнес путем расширения льгот и преференций, а также формирования эффективной системы администрирования и налогового контроля [6]. В 2019 г. в консолидированный бюджет Российской Федерации было собрано 22,5 трлн. руб., в том числе в федеральный бюджет - 12,4 трлн. руб. Основные налоги за указанный период составили: налог на прибыль - 4,5 трлн. руб.; налог на добавленную стоимость - 4,3 трлн. руб.; акцизы - 0,5 трлн. руб.; налог на доходы физических лиц - 3,9 трлн. руб.; имущественные налоги - 1,4 трлн. руб.; налог на добычу полезных ископаемых $-5,9$ трлн. руб. Благодаря администрированию страховых взносов в 2019 году поступило 7,03 трлн. руб. [5].

Однако сформировавшаяся в России система налогообложения с множеством специальных налоговых режимов и налогов усложняет понимание общей налоговой политики государства со стороны хозяйствующих субъектов, способствует незаконной оптимизации, что приводит к формированию теневой экономики. По оценкам Росстата, в российской экономике неформально заняты 14,9 млн. человек, а скрываемый от социальных взносов фонд оплаты труда достигает 10,9 трлн. руб. [7]. В 2018 г. в Российской Федерации выросла неформальная занятость, в результате каждый пятый работающий человек занят неофициально. Наибольшая неформальная занятость зарегистрирована в Чечне (64\%), в Дагестане (52\%), в Ингушетии (48\%) в КабардиноБалкарии (48\%), в Крыму (38\%), в Ставропольском крае (35\%), в Севастополе (34\%) [8]. 
Кроме того, следует добавить, что существование в России единой ставки налога на прибыль для организаций, работающих на принципах общей системы налогообложения и получающих разный объем прибыли, подавляет предпринимательскую активность населения и мотивирует средний бизнес перетекать в теневую экономику, особенно в производственной сфере. В свою очередь, теневая предпринимательская деятельность сокращает доходную часть государственного бюджета, в результате чего растет налоговая нагрузка на легальных участников рынка, для которых могут быть повышены налоговые ставки, введены новые налоги и исключены раннее существующие льготы.

Сторонники конъюнктурно-статистического институционализма, основанного У. Митчеллом (1874 г.-1948 г.), отстаивают идею усиления социального контроля над экономикой и использования различных способов государственного вмешательства в неё. Поэтому целесообразно разрабатывать различные налоговые программы поддержки российского товаропроизводителя, прежде всего для развития наукоемких отраслей промышленности, предприятий функционирующих в сфере высоких технологий и перерабатывающих российское сырьё производств. На этой основе должно повышаться благосостояние всего населения страны. Именно такой цели должна быть подчинена экономическая политика, как в целом, так и в налоговом сегменте.

Прежде всего, при начислении и уплате налогов необходимо соблюдать равенство всех форм собственности (в том числе и государственных корпораций, функционирующих на условиях частного бизнеса), а также использовать ступенчатую шкалу налоговых ставок для равномерного распределения тяжести налогообложения между различными предприятиями. Следует учитывать, что такая шкала не только служит встроенным стабилизатором экономики, но и позволит среднему бизнесу, во-первых, меньше стремиться к укрывательству доходов от налогов и, во-вторых, иметь больше финансовых возможностей для организации на законном основании собственных служб безопасности и охраны.

Установление льгот по налогообложению без изменения психологии агрессивного предпринимательства не окажет существенного влияния на инвестиционную активность населения и фирм, так как при отсутствии полноценного налогового контроля и социальных норм ответственного общественного поведения легче вообще уйти от налогов, чем соблюдать налоговые правила. Переход к рыночным отношениям в условиях неразвитости налоговых органов и ориентации субъектов бизнеса на идеологию так называемого «дикого» капитализма в прошлом периоде уже привел к росту теневой экономики и накоплению значительного экономического потенциала у организованной преступности, а теневые доходы, полученные за счет нарушения налогового законодательства, могут использоваться и для финансирования террористической и экстремистской деятельности [9].

В современных условиях активного применения цифровых технологий при администрировании и контроле за уплатой налоговых платежей, таких как мониторинг, личный кабинет налогоплательщика и т.п., видится необходимым поиск компромиссов между интересами государства и бизнеса в вопросах регулирования налоговой нагрузки, путей снижения рисков незаконного допуска к персональным данным налогоплательщиков. Среди причин незаконного разглашения персональных данных хозяйствующих субъектов могут быть технические сбои, низкая компьютерная грамотность сотрудников, небрежность персонала, недостаточная развитость системы внутреннего контроля, коррумпированность некоторых работников, а также хакерские атаки злоумышленников [10]. Поэтому проблема защиты персональных данных актуальна для всех развитых стран мира [11].

\section{Библиографический список}

1. Налоговый кодекс Российской Федерации (часть вторая) от 05.08.2000 № 117-Ф3 (ред. от 23.11.2020) - режим доступа: http://www.consultant.ru/document/cons_doc_LAW_28165/(дата обращения: 30.03.2021.

2. Налоги и налогообложение: учебник и практикум для академического бакалавриата /под ред. Д. Г. Черника, Ю.Д.Шмелева. - 4-е изд., доп. и перераб. (учебник). М.: Издательство Юрайт.- 2019.

3. Бюджетный кодекс Российской Федерации от 31.07.1998 N 145-Ф3 (ред. от 02.08.2019) (с изм. и доп., вступ. в силу с 01.09.2019) - URL: www.consultant.ru/document/cons_doc_LAW_19702/(дата обращения: 24.10.2019). 
4. Кирова Е.А., Захарова А.В., Самоделко Л. С. Проблемы сближения бухгалтерского и налогового учета / Вестник университета, 2015 г., № 10, с. 222-227.

5. Данные Федеральной налоговой службы Российской Федерации - URL: https://www.nalog.ru/rn77/related_ activities/statistics_and_analytics/forms/8824368/, дата обращения: 18.02.2021.

6. Чернов С. Б., Захарова А.В. Налог на доходы физических лиц как инструмент государственного регулирования экономики: российский и международный опыт / Экономические науки, 2020 г., № 11 (192), с. $266-270$.

7. Солопов М., Старостина Ю., Ткачёв И. Финансовая разведка оценила в Р20 трлн. объем теневой экономики в России - URL: https:/www.rbc.ru/economics/22/02/2019/5c6c16d99a79477be70257еe, дата обращения: 29.10.2019.

8. Фейнберг А. В России выросла неформальная занятость - URL: https://www.rbc.ru/economics/27/03/2019/5c9 a3ea19a7947d947c377c5, дата обращения: 29.10.2019.

9. Чернов С.Б. Политика противодействия финансированию терроризма: определение и угрозы в условиях развития рынка искусственного интеллекта / Экономические науки, 2019 г., № 7 (176), с. 85-92.

10. Чернов С. Б., Новикова О. С. Обеспечение безопасности данных в условиях цифровой экономики / Экономические науки, 2020 г., № 8 (189).- С. 104-109.

11. EU Personal Data Protection Standards and Regulatory Framework. Stepenko, V., Dreval, L., Chernov, S., Shestak, V. / Journal of Applied Security Research, 2021._ URL: https://www.tandfonline.com/doi/full/10.1080/19361610.2 020.1868928? src $=($ accessed 04.04.2021). 